\title{
Pengembangan Modul Matematika Materi Aritmatika Sosial Berbasis Pendekatan Saintifik Untuk Siswa Kelas VII SMP
}

\author{
Maria Editha Bela ${ }^{1}$, Melkior Wewe ${ }^{2}$, Siska Lengi ${ }^{3}$ \\ 1,2,3 Program Studi Pendidikan Matematika, STKIP Citra Bakti \\ Jalan Trans Bajawa Ende, Desa Malanuza, Kecamatan Golewa, Kabupaten Ngada \\ itabella09@gmail.com
}

\begin{abstract}
This study aims to produce a mathematics module with a scientific approach on social arithmetic material in class VII SMP Negeri I Bajawa Utara that meets valid and practical criteria. This type of research that refers to the ADDIE development model, namely analysis, design, development, implementation, and evaluation. Module validation was carried out by two Mathematics education experts. The practicality of the module was tested on five grade VII students of SMP Negeri I Bajawa Utara even semester of the 2019/2020 school year. The research instrument was a module validation sheet, a module practicality sheet, all data collected were analyzed for validity and practicality. The results showed that: the mathematics module with a scientific approach to social arithmetic material in class VII SMP Negeri I is in the very valid category from the material and design aspects with an average score of 4.15, the mathematics module with. The scientific approach to social arithmetic material in class VII SMP Negeri I Bajawa Utara is included in the very practical category with an average score of 4.7. The module already contains steps for a scientific approach that makes the activities of teachers and students have good criteria, the module has made students carry out the learning process in accordance with the rules of the scientific approach so that students get high learning outcomes.
\end{abstract}

Keywords: Development, Mathematics Module, Scientific Approach, Arithmetic

\begin{abstract}
Abstrak
Penelitian ini bertujuan untuk menghasilkan modul matematika dengan pendekatan saintifik pada materi Aritmatika Sosial di kelas VII SMP Negeri I Bajawa Utara yang memenuhi kriteria valid dan praktis. Jenis penelitian ini adalah penelitian yang mengacu pada model pengembangan ADDIE yaitu analysis, design, development, implementation, dan evaluation. Validasi modul dilakukan oleh dua orang ahli pendidikan bidang Matematika. Kepraktisan modul diuji pada lima peserta didik kelas VII SMP Negeri I semester genap tahun ajaran 2019/2020. Instrumen penelitian ini adalah lembar validasi modul, lembar kepraktisaan modul, semua data yang dikumpulkan dianalisis kevalidan dan kepraktisan. Hasil penelitian menunjukan bahwa, modul matematika dengan pendekatan saintifik pada materi aritmatika sosial di kelas VII SMP Negeri I Bajawa Utara termaksud dalam kategori valid dari aspek materi dan desain dengan skor rata-rata 4,15, modul matematika dengan pendekatan saintifik pada materi aritmatika sosial di kelas VII SMP Negeri I Bajawa Utara termasuk dalam kategori sangat praktis dengan skor rata-rata 4,7. Modul sudah memuat langkah-langkah pendekatan saintifik yang membuat aktivitas guru dan peserta didik berkriteria baik, modul sudah membuat peserta didik melaksanakan proses pembelajaran sesuai dengan kaidah pendekatan saintifik sehingga peserta didik memperoleh hasil belajar yang tinggi.
\end{abstract}

Kata kunci: Pengembangan, Modul Matematika, Pendekatan Saintifik, Aritmatika

Copyright (c) 2021 Maria Editha Bela, Melkior Wewe, Siska Lengi

$\triangle$ Corresponding author: Maria Editha Bela

Email Address: itabela09@gmail.com (Jl. Trans Bajawa Ende, Desa Malanuza, Kab. Ngada, Indonesia)

Received 12 Januari 2021, Accepted 03 Maret 2021, Published 10 Maret 2021

\section{PENDAHULUAN}

Pendidikan merupakan upaya sadar yang dengan sengaja dirancang untuk mencapai sasaran yang telah ditetapkan. Pendidikan bertujuan untuk meningkatkan kapasitas sumber daya manusia, dan salah satu usahanya adalah melalui suatu metode pembelajaran di sekolah. Dalam usaha tersebut, pendidik merupakan sumber daya manusia yang harus dibina dan dikembangkan secara terus-menerus (Sahertian, 2000). Cita-cita pendidikan merupakan hal yang paling penting dalam dunia globalisasi saat ini. Pengaruh itu datangnya dari orang dewasa atau yang diciptakan oleh orang dewasa seperti 
lembaga pendidikan, buku, putaran hidup sehari-hari dan sebagainya dan ditujukan kepada orang yang belum dewasa (Harsono, 2011).

Sutama menerangkan bahwa pendidikan merupakan teknik membimbing, melatih dan memandu manusia mengarah puncak potensi kognitif, afektif, dan psikomotorik sehingga terhindar dari ketidaktahuan (Sutama, 2012). Manusia yang berpendidikan dapat berpendapat secara jernih dan akan bertindak secara efektif untuk mencapai suatu tujuan. Dengan demikian pendidikan adalah proses pembentukan karakter manusia untuk mencapai tujuan yang lebih baik. Sasaran pendidikan adalah manusia. Pendidikan bermaksud membantu peserta didik untuk menumbuhkan kembangkan potensi-potensi kemanusiaannya. Undang-undang Nomor 20 Tahun 2003 tentang sistem pendidikan menyebutkan bahwa, kurikulum adalah seperangkat rencana dan pengaturan mengenai tujuan, isi, dan bahan pelajaran serta cara yang digunakan sebagai pedoman penyelenggaraan kegiatan pembelajaran untuk mencapai tujuan pendidikan tertentu (Kemendikbud, 2013). Kurikulum yang sedang berjalan saat ini adalah kurikulum 2013. Kurikulum ini bertujuan untuk mempersiapkan manusia Indonesia agar memiliki kemampuan hidup sebagai pribadi dan warga negara yang beriman, produktif, kreatif, inofatif, dan afektif serta mampu berkontribusi pada kehidupan bermasyarakat, berbangsa, bernegara, dan peradaban dunia.

Dalam kurikulum 2013 diatur bahwa kurikulum untuk SMP/SLTP menggunakan pendekatan Scientifik (pendekatan ilmiah) terutama dalam matematika. Kementerian pendidikan dan kebudayan (2013) menerangkan bahwa metode pembelajaran Scientifik (pendekatan ilmiah) adalah berpaduan antara cara pembelajaran yang semula terfokus pada penelitian, elaborasi, dan konfirmasi dilengkapi dengan mengamati, menanya, menalar, mencoba, dan mengkomunikasikan. Tujuan dari beberapa proses dalam pembelajaran Scientifik (pendekatan ilmiah) menekankan bahwa mencari ilmu tidak hanya berlangsung di ruangan kelas, tetapi juga di lingkungan sekolah dan masyarakat dimana guru berperan sebagai scaffolding ketika siswa mengalami kerumitan, serta guru bukan satu-satunya sumber menggali ilmu. Dengan demikian, pembelajarannya memberikan makna yang utuh kepada siswa seperti tercermin pada berbagai kompetensi dasar (KD) yang tersedia. Kurikulum 2013 memang sudah diterapkan di beberapa sekolah, meskipun demikian pendidikan di tanah air masih menyedihkan.

Berdasarkan hasil pengamatan yang sudah dilakukan di kelas VII SMP Negeri 1 Bajawa Utara, terhadap guru dan peserta didik didapatkan data bahwa rendahnya prestasi belajar peserta didik pada bidang matematika. Diantaranya salah satu pelajaran yang dianggap sulit oleh siswa adalah pelajaran Aritmatika sosial. Kejadian ini dapat dilihat dari keterangan hasil ujian tahun pelajaran 2012/2013 dan keterangan hasil ujian nasional 2013/2014 yang dikeluarkan oleh pusat penelitian pendidikan (puspendik). Hasil analisis UN 2013 dan 2014 kedudukan matapelajaran matematika khususnya pada materi aritmatika sosial sebagai pelajaran yang mempunyai daya serap kecil. Materi aritmatika sosial dipilih karena turunnya presentase kemampuan materi aritmatika sosial pada UN 2014 dibandingkan UN 2013 sebanyak 4,18\%. Pada UN 2013 presentase penguasaan materi 
aritmatika sosial di SMP Negeri 1 Bajawa Utara sebanyak 45,92\% sedangkan pada UN 2014 peresentase penguasaan materi aritmatika sosial di SMP Negeri I Bajawa Utara sebanyak 41,74\%. Dengan mengamatibuktihasil belajar matematika siswa yang belum cocok dengan keinginan, maka diperlukan upaya yang lebih baik lagi untuk kemajuan prestasi belajar matematika siswa. Salah satu dari berbagai upaya peningkatan prestasi belajar matematika siswa adalah dengan penggunaan model pembelajaran yang tepat yaitu model pembelajaran yang berorientasi pada siswa. Aritmatika Sosial merupakan penerapan dari asas perhitungan matematika dalam aktivitas sosial sehari-hari seperti perdagangan, perbankan dan lain-lain. Mereka menerangkan bahwa materi Aritmatika Sosial adalah materi yang sangat sulit dipahami oleh siswa-siswanya. Berbagai metode, strategi, dan pendekatan sudah dilakukan untuk mengatasi hal tersebut, namun belum ada satupun yang berhasil. Hingga saat ini matematika menjadi salah satu dari beberapa bidang yang kurang disenangi justru ditakuti oleh separuh siswa. Hal ini dikarenakan mereka memandang matematika merupakan bidan yang sangat susah untuk dibayangkan. Dengan berbagai materi yang terkandung di dalamnya, pelajaran matematika membuat beberapa siswa merasa takut dan malas untuk mempelajarinya. Adapun materi yang sangat ditakuti dan tidak ditekuni oleh sebagian siswa yakni materi Aritmatika Sosial. Beberapa guru matematika yang ditugaskan untuk memberikan materi ini mengeluhkan hal yang sama. Keluhan tersebut dilontarkan oleh seorangguru sekolah menengah pertama bernama Blandina Du'e, S. Pd yang bekerja di SMP Negeri 1 Bajawa Utara, yang berada di kecamatan Bajawa Utara.

Hal ini terlihat di salah satu sekolah di Kecamatan Bajawa Utara Kabupaten Ngada Provinsi NTT yaitu di SMP Negeri 1 Bajawa Utara. Berdasarkan hasil pengamatan yang dilakukan selama kegiatan Pengenalan Lapangan Persekolahan (PLP) menunjukan bahwa, mata pelajaran Matematika pada materi Aritmatika sosial sulit buat dipahami oleh peserta didik.

Sistem pembelajaran yang di gunakan oleh guru bidang matematika di SMP Negeri 1 Bajawa Utara khususnya di kelas VII masih menggunakan metode ceramah. Kegiatan belajar mengajar tersebut didukung dengan adanya buku paket matematika kurikulum 2013 yang telah disusun oleh dinas pendidikan dan menggunakan buku latihan soal yang siap di pakai. Peserta didik kurang memahami penjelasan materi dari buku panduan belajar yang mereka pakai saat ini karena penjabaran materi dirasa kurang rinci dan terdapat beberapa bahasa yang kurang dipahami oleh peserta didik. Isi dari buku tersebut kurang dilengkapi dengan bagaimana asal usul mendapatkan cara untuk menyelesaikan soal tersebut sehingga mereka tidak bisa mengerjakan atau menyelesaikan soal yang bervariasi serta contoh soal yang diberikan juga masih kurang untuk peserta didik belajar secara mandiri dan juga kurangnya sumber belajar berupa modul. Belum pernah ada buku pembelajaran atau modul yang disusun oleh guru mata pelajaran matematika itu sendiri dengan memperhatikan kemampuan peserta didik. Sedangkan peserta didik tersebut mempunyai kemampuan yang berbeda sehingga menyebabkan waktu yang di butuhkan untuk memahami materi tersebut pun berbeda.

Modul dapat digunakan secara tepat dan bervariasi, seperti untuk meningkatkan motivasi atau gairah belajar, mengembangkan kemampuan dalam berinteraksi langsung dengan lingkungan belajar. 
Modul juga memumgkinkan siswa dapat mengukur atau mengevaluasi sendiri hasil belajarnya dan siswa lebih aktif belajar. Modul yang akan dikembangkan berdasarkan kebutuhan peserta didik serta di lengkapi dengan latihan soal yang berhubungan dengan kehidupan sehari-hari dan disertai dengan gambar-gambar yang menarik tentang aritmatika sosial yang bertujuan untuk menfasilitasi peserta didik belajar mandiri secara aktif sesuai dengan karakteristik kurikulum 2013 yang menghendaki peserta didik secara aktif dapat mengasah kemampuannya sendiri.

\section{METODE}

Jenis penelitian ini menggambarkan penelitian pengembangan yaitu suatu penelitian yang bermaksud menghasilkan suatu produk tertentu dan menghitung kapasitas suatu produk tersebut. Produk yang dihasilkan dalam penelitian ini berwujud Modul dengan pendekatan saintifik pada Materi Aritmatika Sosial untuk SMP kelas VII. Menurut Setyosari (dalam dhiu 2019) penelitian pengembangan merupakan prosedur yang digunakan untuk mengembangkan dan mengkonvirmasi produk bimbingan yang sudah ada. Penelitian pengembangan menekankan produk yang berguna atau bermanfaat dalam berbagai bentuk perluasan, tambahan, dan inovasi dari bentuk-bentuk yang sudah ada. Pengembangan Modul cetak ini menggunakan model pengembangan ADDIE. ADDIE dikembangkan oleh Dick dan Carry untuk merancang sistem pembelajaran. Metode pengembangan ADDIE terdiri dari tahap (Analysis, Design, Development, Implementation, and Evaluation). Dengan langkah-langkah pengembangan yang dipakai dalam penelitian ini mendorong mengikuti langkahlangkah pengembangan ADDIE.

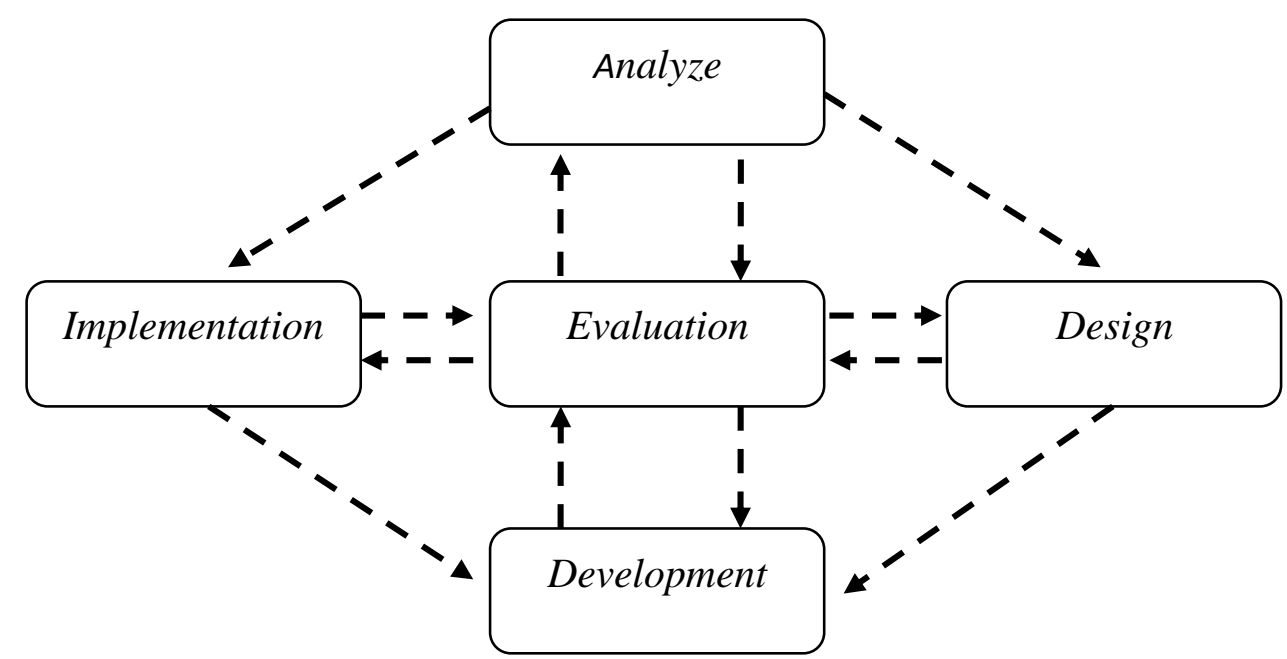

Gambar 1. Model ADDIE

\section{Tahap Analisis (Analysis)}

Jumlah hal yang dilakukan dalam tahap anlisis sebagai berikut.

1. Penjabaran keperluan peserta didik kelas VII untuk mengetahui perkembangan kognitif peserta didikdalam belajar matematika, perlengkapan pembelajaran yang digunakan peserta didik, dan model pembelajaran yang diterapkan kepada peserta didik. 
2. Analisis kurikulum matematika SMP Kelas VII pada bidang aritmatika sosial mencakup SK (Standar Kompetensi) dan KD (Kompetensi Dasar).

3. Analisis karakteristik peserta didik Analisis ini dilakukan untuk melihat kelakuan peserta didik dalam mengikuti pembelajaran, hal ini dilakukan agar pengembangan yang dilakukan sessuai dengan karakteristik peserta didik.

\section{Tahap Desain (Design)}

Kejadian yang dilakukan pada tahap desain yaitu mewujudkan peta kebutuhan bahan ajar, menetukan struktur bahan ajar, menyusun instrumen penelitian, dan validasi instrumen penelitian oleh dosen ahli.

\section{Tahap Pengembangan (Development)}

Hal yang dilakukan pada tahap pengembangan yaitu pembuatan alur belajar hipotetik atau Hypothetics Learning Trajectiry (HLT), penulisan bahan ajar dan validasi bahan ajar oleh ahli materi dan ahli media.

\section{Tahap Implementasi (Implementation)}

Tahap ini merupakan langkah untuk menguji-cobakan produk berupa modul yang telah dikembangkan. Modul diuji-cobakan kepada siswa kelas VII.

\section{Tahap Evaluasi (Evaluation)}

Bagian evaluasi adalah bagian pengukuran terhadap pengembangan bahan ajar dilihat dari komponen kelayakan isi, penyajian, bahasa, dan kegrafikan untuk mengetahui kualitas bahan ajar yang dikembangkan. Selain itu, pada tahap ini dilakukan pula penilaian terhadap evektifitas bahan ajar dalam memfasilitasi pencapaian literasi matematika siswa.

Produk yang dihasilkan dari penelitian ini adalah modul berbasis pendekatan saintifik pada materi aritmatika sosial untuk siswa SMP Kelas VII. Data yang telah dikumpul dalam penelitian ini dianalisis secara deskriptif.

1. Data mengenai kualitas modul cetak aritmatika sosial ini merupakan hasil review ahli dianalisis secara deskriptif untuk mengolah data hasil review ahli materi, ahli desain pembelajaran, dan uji coba siswa. Teknik analisis data ini dilakukan dengan mengelompokan informasi dari data kualitatif yang berupa masukan, tanggapan, kritik, dan saran perbaikan yang terdapat pada angket. Hasil analisis ini kemudian digunakan untuk merevisi produk yang dikembangkan.

2. Data mengenai kualitas modul cetak aritmatika sosial ini merupakan hasil uji coba produk dianalisis melalui konversi skor yang didapat dari lembar kuisioner. Pengubahan hasil penilaian dari guru dan siswa dari bentuk kualitatif ke bentuk kuantitatif menggunakan skala 5 sebagai berikut: SK (Sangat Kurang) skor 1, K (Kurang) skor 2, C (Cukup) skor 3, B (Baik) skor 4, SB (Sangat Baik) skor 5.

3. Kemudian menghitung skor rata-rata tiap sub aspek yang dinilai dengan menggunakan rumus:

$$
\bar{X}=\frac{\sum X}{n}(\text { Belawati dkk, 2006) }
$$


Keterangan :

$\bar{X}=$ skor rata-rata

$\sum X=$ jumlah skor

$n=$ jumlah indikator

4. Terakhir adalah mengganti skor rata-rata tiap sub aspek bobot menjadi nilai bobot sesuai criteria penilaian. Analisis transformasi nilai tiap aspek patokan menjadi nilai kualitatif.

\section{HASIL DAN DISKUSI}

Penelitian dan pengembangan ini menghasilkan sebuah produk berupa Modul Pembelajaran Matematika Materi Aritmatika Sosial dengan Pendekatan saintifikuntuk siswa kelas VII SMP. Modul pembelajaran matematika materi Aritmetika Sosial dengan pendekatan saintifik dalam penelitian ini dikembangkan dengan prosedur pengembangan ADDIE.

\section{Tahap Analisis}

Kebutuhan bertujuan untuk mengetahui sejauh mana pembelajaran matematika di kelas VII SMP Negeri 1 Bajawa Utara dilaksanakan. Pada tahap ini peneliti malakukan wawancara dengan guru mata pelajaran matematika. Wawancara dilakukan pada tanggal 10 juli 2020 dengan narasumber yaitu ibu Blandina Du'e, S.Pd. Salah satu aspek yang dianalisis pada tahap ini adalah kurikulum. Analisis yang dilakukan dalam penelitian ini adalah dengan memperhatikan karakteristik kurikulum yang sedang berjalan di suatu sekolah. Pengembangan yang dilakukan dapat sesuai dengan tuntutan kurikulum. Analisis ini bertujuan untuk mengkaji Kompetensi Dasar (KD), Indikator Pencapaian Kompetensi (IPK) dalam mencapai pembelajaran yang berlaku di SMP Negeri 1 Bajawa Utara. Berdsarakan hasil observasi yang dilakukan dengan siswa di kelas VII SMP Negeri 1 Bajawa Utara didapatkan data bahwa sebagian besar siswa masih mengalami kesuliatan pada materi Aritmatika Sosial. Materi Aritmatika Sosial dalam pembelajaran matematika di kelas VII meliputi Harga Penjualan, Harga Pembelian, Keuntungan, Kerugian, Diskon, Bruto, Netto, Tara, Bunga Tunggal dan Pajak. Salah satu penyebapnya adalah cara belajar siswa yang cenderung menghafal materi dan rumus sehingga tidak ada konsep yang jelas.

\section{Tahap Design}

Pada tahap design ini, komponen modul yang dibuat oleh peneliti bertujuan untuk menjelaskan setiap tahap-tahap penelitian yang berbasis pendekatan saintifik. Isi dari komponen modul yang berbasis pendekatan saintifik ini adalah (a) Ayo mengamati, (b) Ayo bertanya, (c) Ayo mencoba, (d) Ayo menalar, (e) Ayo mengkomunikasihkan. Tampilan screenshot untuk komponenkompponen modul berbasis pendekatan saintifik dapat dilihat pada gambar 2 . 


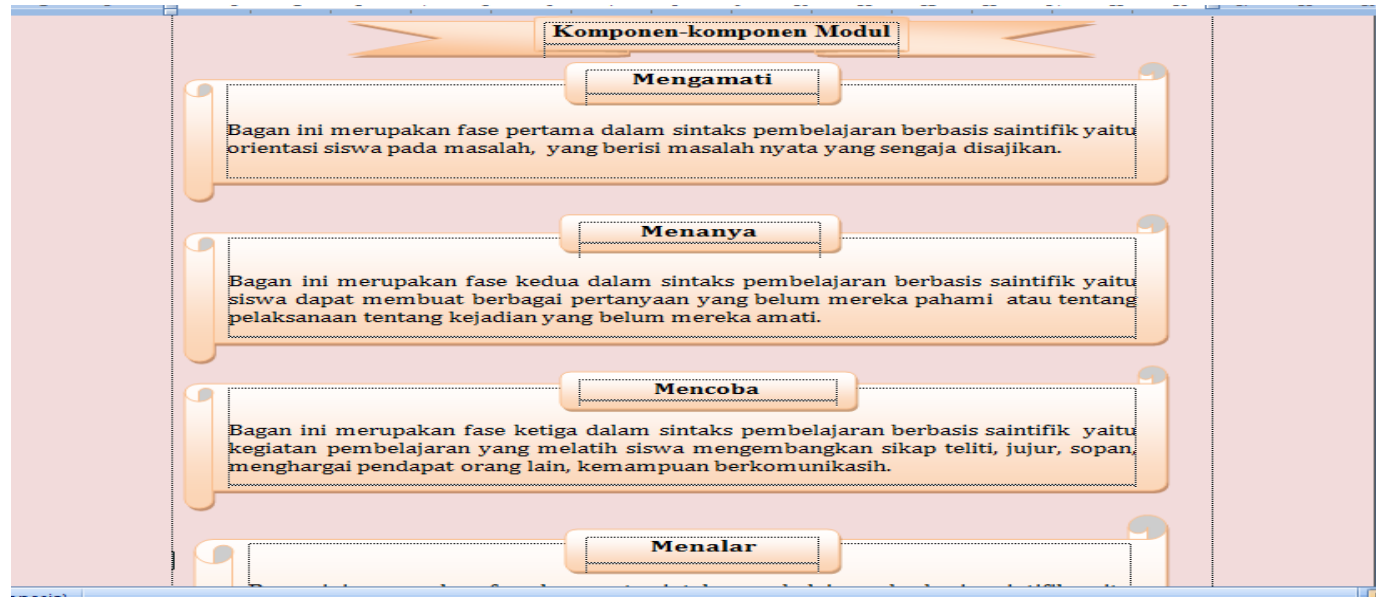

Gambar 2. Komponen Modul Berbasis Pedekatan Saintifik

\section{Tahap Pengembangan (Development)}

Pada tahap pengembangan peneliti melakukan pengujian produk bahan ajar berupa modul aritmatika sosial berbasis pendekatan saintifik yang telah dikembangkan kepada ahli desain, dan ahli materi/konten. Uji coba dilakukan dengan cara memberikan modul kepada ahli-ahli untuk dinilai. Ada dua ahli untuk menilai modul tersebut, yaitu ahli desain dan ahli konten atau materi. Uji coba modul aritmatika sosial dengan ahli desain dilakukan pada tanggal 16 september 2020. Adapun komentar dan saran yang diberikan oleh ahli desain adalah cover dibuat lebih menarik dan gambar pada cover harus sesuai dengan materi, gambar pada kegiatan awal kurang jelas dan harus di ganti warna backroundnya, soal-soal latihan disetiap akhir kegiatan harus memiliki kunci jawaban dan bobotnya masing-masing, gambar pada setiap kegiatan dalam materi jangan berpatok pada nuansa islam, dan layak diujicobakan kepada peserta didik. Dari komentar dan saran di atas peneliti telah memperbaiki sesuai dengan yang diminta oleh ahli desain. Sedangkan uji coba ahli konten atau materi dilakukan pada tanggal 17 september 2020. Adapun komentar dan saran yaang diberikan oleh ahli materi kepada peneliti terhadap modul yang dikembangkan adalah materi aritmatika sosial yang digunakan materi kurang lengkap, perhatikan tanda baca, dan kunci jawaban. Dari komentar dan saran yang diberikan oleh ahli materi, peneliti sudah menambah materi, kunci jawaban, memperbaiki tanda baca.

\section{Tahap Implementasi (Implementation)}

Pada tahap ini peneliti melakukan implementasi hanya terbatas pada sekolah tertentu yaitu SMP Negeri I Bajawa Utara. Tahap ini peneliti lakukan setelah modul aritmatika sosial dinyatakan valid oleh para ahli. Implementasi dilakukan pada kelas VII semester genap tahun ajaran 2019/2020 di lingkungan Watukapu dengan jumlah peserta didik sebanyak 5 orang. Implementasi dilakukan selama 1 hari yaitu pada hari senin 25 Agustus 2020.

\section{Tahap Evaluasi (Evaluation)}

Berdasarkan uraian hasil penelitian di atas, maka tabel rekapitulasi hasil uji coba produk dari setiap ahli untuk mengukur kevalidan bahan ajar dijabarkan dalam tabel berikut ini. 
Tabel 1. Data Hasil Uji Coba Produk untuk Mengukur Kevalidan

\begin{tabular}{|l|l|l|l|l|}
\hline No & \multicolumn{1}{|c|}{ Ahli yang menilai } & \multicolumn{1}{|c|}{ Jumlah skor } & Rata-rata skor & \multicolumn{1}{c|}{ kriteria } \\
\hline 1 & Ahli Desain & 40 & 3,6 & Baik \\
\hline 2 & Ahli Materi & 80 & 4,15 & Sangat Baik \\
\hline
\end{tabular}

Setelah mendapatkan hasil penilaian dari beberapa ahli yang diberikan melalui kusioner mencapai hasil rata - rata 4,15, dan berktiteria "Sangat Baik", Berdasarkan hasil penilaian dari ahli desain kualitas atau mutu produk rata-rata 3,6 dan berkriteria "Baik".

Berdasarkan uraian hasil penelitian di atas, maka tabel rekapitulasi hasil uji coba produk dari guru dan siswa untuk mengukur kepraktisan bahan ajar dijabarkan dalam tabel berikut ini.

Tabel 2. Data Hasil Uji Coba Produk untuk Mengukur Kepraktisan

\begin{tabular}{|l|l|l|l|}
\hline No & Subjek & Rata-rata & Kriteria \\
\hline 1 & Guru Matapelajaran Matematika & 4,5 & Sangat Baik \\
\hline 2 & Peserta didik 1 & 4,5 & Sangat Baik \\
\hline 3 & Peserta didik 2 & 4,6 & Sangat Baik \\
\hline 4 & Peserta didik 3 & 4,7 & Sangat Baik \\
\hline 5 & Peserta didik 4 & 4,8 & Sangat Baik \\
\hline 6 & Peserta didik 5 & 4,7 & Sangat Baik \\
\hline
\end{tabular}

Setelah melakukan uji coba produk terhadap guru dan siswa dan mendapatkan hasil penelitian yang diberikan dalam bentuk angket, kualitas atau mutu produk rata-rata 4,5 dan berkriteria "Sangat Baik", dan berdasarkan hasil penelitian dari guru matematika kelas VII, kualitas atau mutu atau produk rata-rata 4,5 dan berkualitas "Sangat Baik", berdasarkan penilaian (5) siswa kualitas atau mutu produk rata-rata 4,7 dan berkriteria "Sangat Baik".

Berdasarkan data perolehan uji coba untuk mengukur kevalidan dan kepraktisan produk yang dikembangkan di atas telah menjawab rumusan masalah dalam penelitian ini yaitu peneliti menghasilkan modul matematika dengan pendekatan saintifik pada materi Aritmatika Sosial di kelas VII SMP Negeri I Bajawa Utara yang valid dan praktis.

\section{KESIMPULAN}

Bersumber pada hasil penelitian pengembangan modul aritmatika sosial berbasis pendekatan saintifik pada siswa kelas VII SMP dan penjelasan hasil dari penelitian pada bab sebelumnya, maka peneliti dapat menyimpulkan bahwa, Setelah mendapatkan hasil penilaian dari beberapa ahli yang diberikan melalui kusioner mencapai hasil rata - rata 4,15, dan berktiteria“Sangat Baik”, Berdasarkan hasil penilaian dari ahli desain kualitas atau mutu produk rata-rata 3,6 dan berkriteria "Baik", Berdasarkan hasil penilaian dari ahli materi kualitas atau mutu produk rata- rata 4,15 dan berkriteria "Sangat Baik".

Setelah melakukan uji coba produk terhadap guru dan siswa dan mendapatkan hasil penelitian yang diberikan dalam bentuk angket, kualitas atau mutu produk rata-rata 4,5 dan berkriteria "Sangat 
Pengembangan Modul Matematika Materi Aritmatika Sosial Berbasis Pendekatan Saintifik Untuk Siswa Kelas VII SMP, Maria Editha Bela, Melkior Wewe, Siska Lengi

Baik", dan berdasarkan hasil penelitian dari guru matematika kelas VII, kualitas atau mutu atau produk rata-rata4,5 dan berkualiatas "Sangat Baik", berdasarkan penilaian (5) siswa kualitas atau mutu produk rata-rata 4,7 dan berkriteria "Sangat Baik". Penelitian yang dilakukan menghasilkan bahan ajar berupa modul aritmatika sosial berbasis pendekaatan saintifik yang valid dan praktis.

\section{UCAPAN TERIMA KASIH}

Ucapan terima kasih penulis sampaikan kepada:

1. Kepala Sekolah SMP Negeri I Bajawa Utara yang sudah memberikan ijin kepada peneliti dalam melaksanakan penelitian

2. Guru Matematika SMP Negeri I Bajawa Utara yang membantu peneliti dalam melaksanakan penelitian

3. Siswa Kelas VII SMP Negeri I Bajawa Utara sebagai sampel dalam penelitian ini

\section{REFERENSI}

Ahmad, dkk. (2011). Pendidikan dan Masyarakat. Yogyakarta: Sabda Media.

Amri, dkk. (2010). Kronstruksi Pengembangan Pembelajaran. Jakarta: PT Prestasi Pustakaraya

Amri. S. (2013). Pengembangan \&Model Pembelajaran dalam Kurikulum Tahun 2013. Jakarta: PT Prestasi Pustakaraya

Anglada, D. (2007). An introduction to instructional design: Utilizing a basic design model. http://www.pace.sdu/ctlt/newsletter. Diakses tanggal 20 Februari 2019

Arta Rusidarma Putra, (2018), Tujuan Pendidikan.Yogyakarta: Nusa Indah.

Bela, Maria Editha. (2018). Pembelajaran kontekstual untuk materi persamaan linear dua variabel dikelas X siswa SMK. Jurnal Pendidikan Citra Bakti.

Belawati. T \& dkk. (2006). Pengembangan Bahan Ajar. Jakarta: Universitas Terbuka.

Daryanto. (2014). Pendekatan Pembelajaran Saintifik Kurikulum 2013. Yogyakarta: Penerbit Gava Media

Dhiu Vinsensia. (2019). Pengembangan Bahan Ajar Elektronik Multimedia Berbasis Budaya Lokal Ngada Pada Tema Indahnya Keberagaman di Negeriku untuk Siswa Sekolah Dasar Kelas IV di Kabupaten Nga`da. Skripsi. (tidak diterbitkan). Ngada: STKIP Citra Bakti.

Harsono. (2011). Etnografi Pendidikan Sebagai Desain Penelitian Kualitatif. Surakarta: Universitas Muhammaidiyah Surakarta

http://andy-sapta.blogspote.com/2009/01/pengembangan-bahan-ajar-5.html,diakses 14 januari 2013)

Kemendikbud. (2013). Undang-undang republik Indonesianomor 20 tahun 2003 tentang system pendidikannasional. Jakarta: Kemendikbud.

Kemendikbud. (2013). Kerangka Dasar Kurikulum 2013. Kementerian Pendidikan dan Kebudayaan Direktorat Jendral Pendidikan Dasar. Jakarta

Lestari, Ika. (2013). Pengembangan Bahan Ajar Berbasis Kompetensi. Jakarta: AcademiaPermata. 
Nana, Syaodih. (2009). Jenis-jenis Penelitian. Jakarta: Bumi Aksara.

Nugrahani, Permata. (2019). Pengembangan modul matematika materi hubungan antara sudut pada dua garis sejajar untuk kelas VII SMP Regina Pacis Surakarta (skripsi). Fakultas Keguruan Dan Ilmu Pendidikan Sanata Dharma Yogyakarta. (diakses pada tanggal 20 februari 2020)

Prastowo, Andi. (2013). Panduan Kreatif Membuat Bahan Ajar Inovatif. Yogyakarta: Driva Pres.

Ruhimat, Tato.dkk, (2011) Kurikulum dan Pembelajaran. Jakarta .PT Raja Grafindo persada

Sahertian, Piet A., (2000), Konsep Dasar dan Teknik Supervise Pendidikan dalam rangka Mengembangkan Sumber Daya Manusia, Jakarta: Rineka Cipta.

Sudarwan, Danim. (2013), Pengantar Kependidikan, Bandung: Alfabeta,

Sugiyono. (2010). Metode Penelitian Kuantitatif Akualitatif dan $R \& G$. Bandung: Alfabeta

Sutama. (2012). Metode Penelitian Pendidikan. Surakarta: Fairuz Media

Tim Puspendik, Final Report Determinantsof Learning Outcomes TIMMS 2016, (Jakarta Pusat Penilaian Pendidikan Badan Penelitian Dan Pengembangan Kementerian Dan Kebudayaan, 2011)

Umar Tirtarahardja, (2008), Pengantar Pendidikan. Jakarta: Rineka Cipta, hal.

Warsita, Bambang (2011). Pendidikan Jarak Jauh: Perancangan, Pengembangan, Implementasi, dan Evaluasi Diklat. Bandung: PT Remaja Rosdakarya.

Widoyoko, Eko Putro. (2009). Evaluasi Program Pembelajaran (Panduan Praktis Bagi Pendidik Dan Calon Pendidik). Yogyakarta: Pustaka Pelajar 